Relations industrielles

Industrial Relations

\title{
Posusney, Marsha Pripstein, Labor and the State in Egypt
}

\section{Bassirou Tidjani}

Volume 55, numéro 1, 2000

URI : https://id.erudit.org/iderudit/051303ar

DOI : https://doi.org/10.7202/051303ar

Aller au sommaire du numéro

Éditeur(s)

Département des relations industrielles de l'Université Laval

ISSN

0034-379X (imprimé)

1703-8138 (numérique)

Découvrir la revue

Citer ce compte rendu

Tidjani, B. (2000). Compte rendu de [Posusney, Marsha Pripstein, Labor and the State in Egypt]. Relations industrielles / Industrial Relations, 55(1), 187-191.

https://doi.org/10.7202/051303ar

Tous droits réservés (C Département des relations industrielles de l'Université Laval, 2000
Ce document est protégé par la loi sur le droit d'auteur. L'utilisation des services d'Érudit (y compris la reproduction) est assujettie à sa politique d'utilisation que vous pouvez consulter en ligne.

https://apropos.erudit.org/fr/usagers/politique-dutilisation/ 
- La répression antisyndicale a pris la forme de congédiements, mais aussi d'interventions musclées des occupants américains, de union-busting, notamment par l'aide à la mise sur pied d'autres syndicats (second union), qui s'épanouissaient d'autant facilement que tous les leaders des premiers avaient été mis hors de combat.

- Les tentatives des travailleurs japonais de former des organisations et d'articuler des luttes sectorielles ont été mises en déroute, d'où l'avènement du company unionism, calqué sur le modèle américain ; la mise sur pied de comités d'entreprises (strictement consultatifs) ont permis à certains de diagnostiquer une certaine influence du modèle allemand.

En dernier ressort, il pourra être intéressant de consulter ce livre pour y constater que, loin d'être « en retard», les militants japonais d'après-guerre ont mis de l'avant des pratiques et revendications reprises par la suite en Occident dans les années 1970 sous le nom d'autogestion. Elles furent bien sûr réprimées par l'occupant américain, de même que fut interdite une grève générale (1 ${ }^{\text {er }}$ février 1947), cette dernière appelée dans un climat véritablement prérévolutionnaire (il était question de renverser le gouvernement). Parallèlement aux conflits dits « du travail » prirent place des manifestations populaires contre la faim ; la population était affamée, rationnée, les denrées bloquées dans des entrepôts, la récolte de riz désastreuse... C'est cette conjoncture qui donne son titre, qui peut autrement avoir l'air saugrenu, au livre: The HUMAN Face of Industrial Conflict in Post-War Japan, les conflits de travail étant aussi centrés sur l'accès à un minimum vital.

Traverse ce livre l'inéluctabilité de l'existence de diverses factions politiques au sein du mouvement syndical, habilement exacerbée par le patronat. De même que l'acharnement des forces combinées de la puissance occupante, du patronat et du gouvernement japonais pour empêcher la construction/consolidation d'un syndicalisme japonais combatif. Somme toute, ce livre est bienvenu comme antidote à un certain nombre de clichés à combattre et pour mettre de l'avant une ou deux idées-forces. Ainsi que le syndicalisme, qu'il soit d'ici ou d'ailleurs, est un produit sociohistorique, et que le syndicalisme japonais a derrière lui une histoire de militantisme $e t$ de répression qui le distinguent.

MONA-JosÉE GAGNON Université de Montréal

\section{Labor and the State in Egypt}

by Marsha Pripstein POSUSNEY, New York : Columbia University Press, 1997, 327 p., ISBN 02-3110-692-0.

Structural adjustment programs (SAP) in African countries have been a historical turning point. For labour and its organizations, SAPs have been a test of their capacity to respond to radical environmental change after the long period of relative stability following independence. For students in industrial relations and labour studies, SAPs are an opportunity for comparative analysis of labour's response to these changes. They also raise questions about the old para- digms concerning the relationship between the state, labour, employers and the general society on issues of economic development and nation building.

Most analyses concern only the impact of SAPs on workers, their unions and their working conditions (B. Tidjani, "African Unions under Structural Adjustment Programs," Relations industrielles/ Industrial Relations, Vol. 53, No. 2, 1998). Posusney's Labor and the State in Egypt offers both an understanding of 
how Egyptian labour protected workers' interests and an explanation of why they adopted specific patterns of responses under SAPs. This review first highlights the important contribution of this book and then considers the importance of historical factors in explaining labour capacity under SAPs and the adequacy of the author's moral economy approach for a comparative understanding of African labour under SAPs.

\section{The Contribution of the Book}

Taking a clear pro-labour stand and moving from the Nasirist era to underline traditions of struggle in the Egyptian labour movement, Posusney argues that despite repressive and authoritarian regimes, workers have been able to affect governmental policies, especially the restructuring and privatization strategies of the State in the 1980s and 1990s. The impasse over privatization, particularly under the Mubarak government, is presented as a compelling demonstration of the centrality of the labour movement to the structural adjustment process. Evidence of this centrality include the requirement that mass layoffs be submitted to government authorization, the imposition of restrictions on individual firings, the struggle for a quid pro quo between the rationalization of labour markets as advocated by employers and international funding agencies on one side and the liberalization of strikes and the late enactment of the new labour law.

In the corporatist Egyptian industrial relations system, this centrality of labour has to be analyzed as the outcome of an interactive process between labour and the State, not as the result of the unilateral activities of labour. Posusney argues that the government's propensity to implement reforms is largely shaped by its perception of the likelihood of labour opposition, because what matters the most for its members is legitimacy.

Posusney's work is an important methodological and theoretical contribu- tion to the study of labour in Africa under SAPs. Methodologically, it combines historical/institutional and individual choice-oriented analyses to explain labour and State relations in Egypt. This methodological choice is based on the assumption that while an institutional/historical focus allows to understand how existing rules and structures shape, stimulate or impinge on the options available to relevant actors, they must be completed with an interpretative examination of the latters' beliefs and motives to explain their final choices. Although these two methodological dimensions have been present in several studies of labour in Africa, they are generally treated separately. History and institutions have been used to argue in favour of continuity, national diversity or convergence. Individual choice paradigms have most often served to explain unions' leaders betrayal of their members. This emphasis on individual choice suggests another sociological definition of the worker in the African environment where the individual is traditionally largely subordinated to the collective interest. For Posusney, workers are individuals, each with a unique temperament and a different set of personal circumstances which influence their attitude toward their working conditions and determine their responses to any change in these. However, in order to influence policy-making at the plant, industrial or national level, collective action is necessary. Where traditional studies of labour (especially institutionalists) implicitly or explicitly see contradictions, Posusney sees complementarity thought it should be acknowledged that the worker as an individual is not always very present in her analysis of Egyptian labour.

This is because of the author's theoretical approach and its impact on her unit of analysis. Adopting a moral economy approach to the dynamics of labour and State relationship and workers' reactions to economic restructuring 
in Egypt, the argument is as follows. Etatism initiated by Nasir created the belief in a moral economy in which wages and benefits are viewed by workers as entitlements in exchange for their engagement in national economic development. Therefore, attempts by Sadate and Mubarak, under the pressures of multilaterals (World Bank and IMF) to encourage State's withdrawal from its traditional economic and social commitments' are perceived by workers as violations of norms and standards to and as a rupture of the moral contract between the State and labour.

Reference to the moral economy as a theoretical framework means that in addition to viewing the State and union leaders (instead of management and local leaders) as the main actors, it gives a priority to public sector enterprises and focuses on the macro level as a unit of analysis. In fact as we moved toward the 1990 s and more privatization, we expected private sector workers to be the locomotive of the Egyptian labour movement and a shift of emphasis from macro to plant level analyses. Instead, plant level worker mobilization is too often presented by the author as a worker's reaction to the betrayal of top level union leaders. This theoretical choice explains why collective action is more relevant to Posusney's analysis than individual will despite her innovative definition of the worker as an individual.

\section{The Importance of Formative Periods in Explaining Labour Capacity under SAPs}

Despite the author's argument that history and institutions do not suffice to explain workers' actions in Egypt during the 1990s, the formative period of the Egyptian labour movement appears as a key explanatory factor of labour capacity under SAP. In the post-colonial era, most African states adopted corporatism as the royal path toward nation building and economic development. What it fundamentally entailed was the subordination of workers' interests to the collective interest of the nation. However, to refer to the single label of corporatism to identify the different regimes established in African countries during the post-colonial era does not capture differences between Senegalese unfinished corporatism, Guinean overwhelming and repressive corporatism and weak Egyptian corporatism. What these various forms share is the absence of the democratic elements which characterize European corporatism and allow workers to formulate, implement and evaluate national strategies to deal with capital. Variations between them result from internal factors. In most African countries, the role played by unions in the anti-colonial struggle inevitably made them actors in the process of nation building. Indeed, in many countries, the first presidents and ministers were former union leaders. In other words, corporatism was internally built.

Several factors make Egypt a case of weak corporatism. First, Nasirism emerged from a military coup which brought to power officers whose linkages to the civil society, and especially to unions, were almost inexistant. Second, our interpretation of Posusney's analysis of Nasirism is that the corporatist State in Egypt was externally inspired, not internally built. Third, at the time of the 1952 military coup, labour was weak and did not have a history of strong participation in Egypt anti-colonial struggle or in the struggle for Arab unity. So, it had little capacity to bargain over power and participation in future developmental strategies. Under Nasir (1952-1961), the only really worker-led action was the KafralDawwar strike which occurred less than a month after the free officers' coup. The March $26^{\text {th }}$ action in 1954 was manipulated because it resulted from a split within the political leadership of the nation.

Although Posusney argues that union responses to reform initiatives vary 
overtime as well as across issues, it is possible to identify a pattern which originated from the Nasirist era. First, it entails a system of labour relations dominated by the State whose major preoccupation has been its control over senior unionists and little emphasis at the local level where leftists operate, because it became clear to the State that leftists did not have the capacity to seriously challenge its control over the trade union confederation leadership (for example, the extent to which, under Mubarak, the Egyptian Trade Union Federation (ETUF) had come to view itself as a branch of the ruling party). Second, the labour movement is characterized by a weak organizational maturity. Although the threat of the creation of an independent confederation was often evoked (especially by leftists), it was never taken seriously, neither by the State nor by its advocates. In African countries where these capacities existed, autonomous confederations emerged (for example Senegal) and competed with traditional ones. Thus, what Posusney characterizes as senior unionists' opportunism and individual choices may well be interpreted as a lack of organizational resources due to decades of State domination over Egyptian labour relations.

Although Posusney is correct when she sees institutions and structures of labour relations as a contested terrain or an arena of political struggle in which forces seeking alternative ways (leftists in Egypt) compete with those favouring the status quo (government and some senior unionists in Egypt) and reach their goals through what she characterizes as political constructivism, the point is that the labour movement in Egypt has not yet been able to construct an independent confederation.

\section{In Search of New Paradigms ?}

Compared to other theoretical frameworks, most of them state-centred (new international division of labour, bureaucratic-authoritarian, rational choice, neo-marxist), the moral economy approach used by Posusney better explains the Egyptian case. But, does it do it well enough?

The moral economy approach leads to an understanding of workers in Egypt not as revolutionaries seeking alternative relations between labour, state and capital, but as conservatives, at best reformists. Even under SAPs, the main objective of labour's protest has not been a redefinition of the terms of their exploitation but to restore the previous order where workers are entitled to salaries, benefits and job security in exchange for their participation in economic development.

Such a view presents several drawbacks and seems to contradict Posusney's pro-labour stand. First, it leads to a greater emphasis on categories of labour who protest but at the same time struggle to maintain traditional corporatist arrangements than on categories who struggle for autonomous unions. The intention here is not to challenge the author's well-documented narrative but there is a need for a more detailed account of locals' and leftists' protests, especially those aiming at labour autonomy. Second, because the moral economy put an emphasis on conservative categories of labour, it does not allow for a good account of emerging labour strategies mostly stimulated, if not imposed by SAPs. Third, by putting less emphasis on emerging strategies, reliance on the moral economy approach slows down processes of theory building in the study of labour in Africa.

Posusney seems very much aware of the challenges that Egyptian workers and their traditional organizations will face during the coming decades. She states very aptly that "it is not clear that the ETUF is organizationally suited for the challenges that lie ahead. The single, centralized, hierarchical labour confederation which helped workers fend off a reversion to neo-liberal capitalism 
is not necessarily the best formation to help them protect their interests while living under it" (p. 242). In her examination of the consequences of the collective bargaining provisions in the new labour legislation, she predicts that "as the performance of locals and federations become more important to workers' paychecks, the hierarchical functioning of the ETUF will come under increasing challenge."

In Egypt as in many other African countries, does privatization not render top level bargaining between union leader and the State more and more irrelevant to plant level issues, thus separating the political aspects of labour relations (top level bargaining) from its economic aspects (plant level issues) ? The debate may be even more complex in light of recent attempts by leaders of autonomous unions in Africa to run for president, successfully in Zambia and now in process in Zimbabwe and Senegal. In these cases, we are not witnessing a separation between politics and economics but a new relationship between unions, politics, the State and the civil society and the emergence of new regimes of labour relations.

Research on labour in Africa will gain in addressing more extensively unfolding paradigms because of changing contexts. The moral economy does not allow for that because it is based on the assumption that both the State and labour want the status quo despite the changing environment. There is a need, therefore, for a more constructivist paradigm which better integrates : the new categories of labour; the complexities of collective bargaining due to greater interdependence between local, regional and global issues; the effects of these complexities on the structure of unions and on workers' reliance on alternative types of organizations for the defence of their interests; the different forms of labour contribution to economic development and the extent to which workers should participate in macro and micro levels decision making processes ; the impact of this participation on union leaders' economic and political expertise ; and whether African unions are moving towards more business unionism or political unionism or both.

Because of its historical scope, depth and theoretical foundations, Posusney's Labor and the State in Egypt is one the most comprehensive research efforts on labour relations in Africa under SAPs. It strongly underscored the need for similar studies on other African countries within a comparative framework.

Attempts by governments and business (especially in industrialized countries) and international funding agencies (particularly in the third world) to advocate the irrelevance of unions to the defence of workers' interests and to sustained economic development must increase our interest for Posusney's work. We share her optimistic view on unions in Egypt when she states that "the irony of the situation should not be lost : with their surrender in the battle for preservation of the parastatals, which was the ETUF's rallying cry for two decades, the unions stand to regain the raison d'être that was largely lost when the public sector was first created" (p. 241). The question to be answered is which unions?

\author{
BASSIROU TIDJANI \\ Université Cheikh Diop \\ Dakar, Senegal
}

